Bangladesh J. Pl. Breed. Genet., 28(2): 09-16, 2015

\title{
MORPHO-PHYSIOLOGICAL AND BIOCHEMICAL TRAIT BASED SELECTION OF WHEAT GENOTYPES FOR DROUGHT TOLERANCE
}

\author{
Sharif-Ar-Raffi* and Asaduzzaman \\ Department of Genetics and Plant Breeding \\ Bangladesh Agricultural University, Mymensingh 2202 \\ *Corresponding author: saraffi@ bau.edu.bd
}

\begin{abstract}
Drought stress is now become the most important abiotic stress for wheat in Bangladesh. Rabi season often compromised wheat production by imposing drought stress. Therefore, it has been a priority to develop drought tolerant wheat variety for Bangladesh. However, the lack of genetic variability for drought tolerance in wheat has been a major bottleneck for developing drought tolerance wheat variety. The present investigation was carried out in an aim to evaluate several exotic and locally cultivated wheat genotypes for drought tolerance based on morpho-physiological and biochemical traits. Experiment was carried out at the net house of Field Laboratory of Department of Genetics and Plant Breeding, Bangladesh Agricultural University, Mymensingh with seven replications in a RCBD design. Ten locally cultivated and exotic wheat genotypes were grown under control (100\% field capacity) and drought ( $30 \%$ field capacity) conditions. Genotypes used in the study were identified with different types of drought tolerance mechanisms, viz., Berkut for earliness, Shatabdi for grain weight, BARI Gom 26 for spike and grain number, along with Vorobey, Berkut for enhanced biosynthesis of proline, Sokoll for undamaged leaf Chlorophyll content and relative water content, Sakha8, Gaurav, Sonalika and Shatabdi for membrane thermostability; Sakha8 and Sourav for improved stress tolerance index. The genotypes screened out with different traits related to drought tolerance can be utilized as gene source for future breeding programs.
\end{abstract}

Keywords: Wheat (Triticum aestivum L.); stress; drought; membrane thermostability

DOI: http://dx.doi.org/10.3329/bjpbg.v28i2.29961

\section{INTRODUCTION}

Drought is a major stress that compromise crop yield around the world (Reddy et al., 2004). In Bangladesh, Rabi crops are usually affected by the drought stress as winter is almost dry (Rahman et al., 2009). Developing drought tolerant crop variety (e.g. wheat) for Rabi season has been, therefore, a major objective for the breeder for last few decades in Bangladesh (Siddiqui et al., 1999; 2000). Plants adapt to drought stress by different mechanisms, including changes in morphological and developmental patterns as well as physiological and biochemical processes (Bohnert et al., 1995). However, majority of the attempts of improving drought tolerant wheat cultivars were based on the emphasized evaluation of yield contributing morphological characters (Hossain and Teixeira Da Silva, 2012; Siddiqui et al., 1999; 2000; Rahman et al., 2009; Hakim et al., 2012), with less emphasis for biochemical and physiological traits. Country's cultivated high yielding wheat varieties have to eventually compromise their yield due to drought susceptibility, whereas, several exotic landraces and wild wheat are found to have profound drought tolerance but lower grain yield. Thus, selection for drought tolerant 
sources in landraces and wild wheat based on the yield contributing traits could be misleading (Dodd et al., 2011). Furthermore, certain biochemicals are found synthesized in stressed condition to confer drought tolerance by providing osmo-regulation, like, proline (Pospíšilová and Batková, 2004), abscisic acid (ABA) (Quarrie et al., 1999) as well as some drought induced physiological traits (Reynolds et al., 2007). Among the physiological traits, traits to maintain uninterrupted photosynthesis viz., leaf chlorophyll content (Pask et al., 2012), keeping cell structure integrity viz., membrane thermostability (Cave, 1981; Buchanan et al., 2000), keeping turgid leaf viz. relative water content (RWC, Almeselmani, 2011) or resultant stress tolerance index (STI) have been the prime traits to consider. The yield related traits along with biochemical and physiological diagnosis can be of better aids to distinguish between drought stress susceptible and poor yielded drought tolerant wheat lines towards utilizing the genetic sources. The genotypes screened with above mentioned morphological, physiological and biochemical traits can be used as parents for synthesizing drought tolerant wheat genetic stocks towards developing drought tolerant wheat variety. The present investigation was, therefore, aimed to evaluate several locally cultivated and exotic wheat genotypes for drought tolerance based on morphological, physiological and biochemical traits that are known to confer drought tolerance in wheat.

\section{MATERIALS AND METHODS}

\section{Plant materials}

Ten wheat genotypes including five exotic genotypes were used as experimental materials in this study are presented in Table 1.

Table 1. Wheat genotypes used as experimental materials in this study with sources

\begin{tabular}{l|l|l|l|l|l}
\hline Sl. & Genotype & Source & Sl. & Genotype & Source \\
\hline i. & Vorobey & CIMMY* & vi. & BARI Gom 26 & RWRC, BARI** \\
ii. & Shorawaki & CIMMYT & vii. & Sourav & RWRC, BARI \\
iii. & Sakha 8 & CIMMYT & viii. & Gaurav & RWRC, BARI \\
iv. & Berkut & CIMMYT & ix. & Sonalika & RWRC, BARI \\
v. & Sokoll & CIMMYT & x. & Shatabdi & RWRC, BARI
\end{tabular}

*International Wheat and Maize Improvement Centre, Mexico; ** Regional Wheat Research Centre, Bangladesh Agricultural Research Institute, Gazipur, Bangladesh

\section{Experimentation}

Pot preparation:

The experiment was conducted in pot. About $8.2 \mathrm{~kg}$ of soil was taken in a pot. The soil was silty loam in texture having $\mathrm{pH} 6.7$, organic $\mathrm{C} 0.65 \%$, total $\mathrm{N} 0.09 \%$ and available $\mathrm{P}$ $9.3 \mu \mathrm{gg}$. The pot soil was saturated with water and kept for overnight. After that, pot was weighed again, the difference between $2^{\text {nd }}$ weight and $1^{\text {st }}$ weight was the weight of water which contributed to $100 \%$ field capacity.

\section{Plant culture:}

Seeds were germinated in petridishes, and then transplanted while five days old. Two plants of different genotypes were planted in each pot. Experiment was conducted in a RCBD design with seven replications. Therefore, 70 pots were maintained considering two treatments, 10 genotypes, seven replications and two plants per pot. Intercultural 
operations viz. weeding, fertilization etc. were done as recommended, whenever necessary.

Experiment was conducted during November/2014 to April/2015 at the net house of Dept. of Genetics and Plant Breeding, Bangladesh Agricultural University, Mymensingh.

\section{Drought induction:}

Drought condition was induced by maintaining 30\% field capacity of moisture, based on the amount of required for $100 \%$ field capacity (FC) according to the procedure followed in Khakwani et al. (2011). Control treatment had 95-100\% of field capacity of moisture in pot soil. Drought treatment was induced when plant were two weeks of old after transplanting and continued until maturity.

\section{Data collection:}

Data were collected in different levels of growth, maturity and post harvest stages according to the standard procedure practiced in previous attempts (Bates et al., 1973; Farshadfar et al., 2008; Saeedipour and Moradi, 2011, Punia et al. 2011, Fernandez, 1992) on following parameters (Table2).

\section{Table 2. Traits considered for the study}

\begin{tabular}{|c|c|c|c|}
\hline Traits & Type of trait & Traits & Type of trait \\
\hline $\begin{array}{l}\text { Flag Leaf Proline } \\
\text { content }\end{array}$ & Biochemical & $\begin{array}{l}\text { Days to } \\
\text { anthesis }\end{array}$ & $\begin{array}{l}\text { Yield contributing } \\
\text { and morphological }\end{array}$ \\
\hline $\begin{array}{l}\text { Flag Leaf Chlorophyll } \\
\text { (SPAD) content }\end{array}$ & Physiological & $\begin{array}{l}\text { Days to } \\
\text { maturity }\end{array}$ & $\begin{array}{l}\text { Yield contributing } \\
\text { and morphological }\end{array}$ \\
\hline Relative Water Content & Physiological & $\begin{array}{l}\text { No. of spike } \\
\text { per plant }\end{array}$ & $\begin{array}{l}\text { Yield contributing } \\
\text { and morphological }\end{array}$ \\
\hline Cell membrane leakage & Physiological & $\begin{array}{l}\text { No. of grain } \\
\text { per spike }\end{array}$ & $\begin{array}{l}\text { Yield contributing } \\
\text { and morphological }\end{array}$ \\
\hline Stress Tolerance index & Physiological & $\begin{array}{l}1000 \text { Kernel } \\
\text { weight. }\end{array}$ & $\begin{array}{l}\text { Yield contributing } \\
\text { and morphological }\end{array}$ \\
\hline Plant height $(\mathrm{cm})$ & $\begin{array}{l}\text { Yield contributing } \\
\text { and morphological }\end{array}$ & $\begin{array}{l}\text { Grain yield per } \\
\text { plant (g/plant) }\end{array}$ & $\begin{array}{l}\text { Yield contributing } \\
\text { and morphological }\end{array}$ \\
\hline
\end{tabular}

Data analysis:

Data recorded on the traits mentioned in Table 2 were managed in MS Excel ${ }^{\circledR}$ and analyzed by MINITAB ${ }^{\circledR} 14$, a computer based statistical package.

\section{RESULTS AND DISCUSSION}

ANOVA of the traits were presented in Table 3. Mean performances of the genotypes for the traits considered were presented in Table 4. Percent changes in performance due to drought stress for the traits considered in genotypes due to drought stress were presented in graphs (Fig 1A-D). All the genotypes studied showed significant differences for all the traits and treatments were found significantly different from each other, as well. 
Table 3. ANOVA for the traits conferring drought tolerance and grain yield in $\mathbf{1 0}$ wheat genotypes

\begin{tabular}{l|c|c|c}
\hline Characters & $\begin{array}{c}\text { Genotypes } \\
(\mathrm{df} 9)\end{array}$ & $\begin{array}{c}\text { Drought treatment } \\
(\mathrm{df} 1)\end{array}$ & $\begin{array}{c}\text { Error } \\
(\mathrm{df} 138)\end{array}$ \\
\hline Plant height $(\mathrm{cm})$ & $374.955^{* *}$ & $1631.565^{* *}$ & 9.965 \\
Days to anthesis & $113.148^{* *}$ & $735.00^{* *}$ & 0.80 \\
Days to maturity & $147.41^{* *}$ & $904.82^{* *}$ & 4.08 \\
No. of spike per plant & $1.108^{* *}$ & $53.998^{* *}$ & 0.07 \\
No. of grain per spike & $44.71^{* *}$ & $1153.69^{* *}$ & 3.70 \\
1000 kernel weight. & $106.981^{* *}$ & $781.99^{* *}$ & 15.26 \\
Grain yield per plant & $2.22^{* *}$ & $140.67^{* *}$ & 0.21 \\
Flag leaf Proline & $3.470^{* *}$ & $288.380^{* *}$ & 0.680 \\
Flag leaf Chlorophyll & $365.31^{* *}$ & $878.83^{* *}$ & 28.06 \\
Relative Water Content & $106.57^{* *}$ & $3753.93^{* *}$ & 2.56 \\
Cell membrane leakage & $48.37^{* *}$ & $3082.81^{* *}$ & 8.25 \\
\hline
\end{tabular}

** indicates significant at $1 \%$ level of significance

Among the genotypes, BARI Gom 26 along with Vorobey, Sakha8, Berkut and Sokoll maintained highest plant height even at drought stress. Again BARI Gom 26 along with Sourav and Sonalika took least possible time for anthesis and maturity. Earliness in terms of heading, anthesis, grain filling or maturity are common mechanisms of drought tolerance in wheat, as these helps the plant to escape or avoid the intense effect of stress before maturity (Pask et al., 2012). Number of spikes per plant was found higher in BARI Gom 26, followed by Vorobey, Sokoll and Shatabdi. Increased spike number even at stressed condition indicates plant's inherent ability to continue its growth i.e. drought tolerance (Punia et al., 2011). Grain number was again found highest in BARI Gom 26 along with Vorobey and followed by Sakha8. Number of grain has a positive correlation with yield, therefore, genotypes with higher grain number per spike even at drought stress believed to have potentials of drought tolerance (Pask et al., 2012). 1000 Kernel weight was found more in Shatabdi, whose grain number per spike was least. Other genotypes followed Shatabdi were Shorawaki, BARI Gom 26, Sourav, Gaurav and Sonalika. This is a common phenomenon in cereals, as grain number and individual grain weight are inversely correlated (Adhikary et al., 2009). Grain yield per plant was found highest in BARI Gom 26, followed by Sonalika, Shatabdi and Vorobey. This trend proved again that the selection of genotypes based on theyield for drought tolerance is not always dependable (Dodd et al., 2011). Among the geneotypes, Sakha 8 and Sourav has found to be least affected by drought stress (Fig 1A).

Genotypes demonstrated significantly different proline content in flag leaf, where, Berkut accumulated highest amount of proline in flag leaf in drought stressed condition, followed by Sokoll and BARI Gom 26 (Table 4; Fig 1B). The accumulation of proline in plant tissues is a clear indication of plants inherent ability of tolerance against environmental stress, particularly in plants under drought stress (Routley, 1966). Proline accumulation may also be part of the stress signal influencing adaptive responses (Maggio et al. 2002). Therefore, the more the proline, better the ability of plants to withstand drought, which is one of the most common compatible osmolytes in drought stressed plants. 
Table 4. Mean performances of the 10 wheat genotypes for traits conferring drought tolerance

\begin{tabular}{l|c|c|c|c|c|c|c|c|c|c|c|c|c}
\hline \multicolumn{1}{c}{ Genotype } & PH & DTA & DTM & NSPP & GRSP & $\begin{array}{c}1000 \\
\text { KW. }(\mathrm{g})\end{array}$ & GYP $(\mathrm{g})$ & $\begin{array}{c}\text { FL Pro } \\
\left(\mu \mathrm{mol} \mathrm{g} \mathrm{fw}^{-1}\right.\end{array}$ & Fl. Chl. & RWC & CML & STI \\
\hline Vorobey & 79.44 & 82.50 & 111.7 & 4.16 & 33.95 & 34.27 & 3.46 & 2.59 & 43.78 & 88.47 & 23.35 & 0.389 \\
Shorawaki & 74.78 & 78.50 & 108.3 & 3.50 & 30.08 & 38.65 & 2.93 & 2.47 & 48.88 & 83.04 & 23.10 & 0.367 \\
Sakha 8 & 76.88 & 78.67 & 109.2 & 3.70 & 32.30 & 35.27 & 2.90 & 2.70 & 54.38 & 86.11 & 17.01 & 0.513 \\
Berkut & 79.92 & 73.33 & 103.5 & 3.29 & 29.53 & 39.67 & 2.70 & 4.43 & 40.51 & 84.90 & 23.81 & 0.410 \\
Sokoll & 79.27 & 87.50 & 118.3 & 4.20 & 31.25 & 35.89 & 3.39 & 3.29 & 55.49 & 93.14 & 23.27 & 0.353 \\
BARI Gom 26 & 80.09 & 75.00 & 106.3 & 4.80 & 34.77 & 39.30 & 4.70 & 3.46 & 48.08 & 93.32 & 20.40 & 0.384 \\
Sourav & 59.34 & 76.33 & 150.2 & 3.78 & 29.18 & 42.19 & 3.24 & 2.17 & 36.68 & 83.50 & 22.64 & 0.449 \\
Gaurav & 59.86 & 73.50 & 100.7 & 3.90 & 26.05 & 38.40 & 2.85 & 2.71 & 34.68 & 81.02 & 17.42 & 0.290 \\
Sonalika & 70.72 & 76.00 & 107.5 & 4.50 & 28.17 & 41.31 & 3.59 & 1.73 & 36.15 & 86.91 & 17.77 & 0.312 \\
Shatabdi & 71.77 & 77.00 & 103.8 & 4.07 & 28.20 & 48.95 & 3.97 & 2.38 & 36.52 & 83.09 & 18.12 & 0.353 \\
Minimum & 59.34 & 73.33 & 100.7 & 3.29 & 26.05 & 34.27 & 2.70 & 1.73 & 34.68 & 81.02 & 17.01 & 0.290 \\
Maximum & 80.09 & 87.50 & 118.3 & 4.80 & 34.77 & 48.95 & 4.70 & 4.43 & 55.49 & 93.32 & 23.82 & 0.513 \\
\hline \multicolumn{1}{c}{ LSD (0.05) } & 3.69 & 1.05 & 2.36 & 0.31 & 2.25 & 4.57 & 0.54 & 1.02 & 6.19 & 1.87 & 3.36 & 0.094 \\
\hline
\end{tabular}

$\mathrm{PH}=$ Plant height DTA= Days to anthesis; DTM= Days to maturity, NSPKP= No. of spike per plant, GRSPK= Grain per spike, $1000 \mathrm{KW}=1000$ kernel weight, $\mathrm{GYP}=$ Grain yield per plant, FL Pro= Flag leaf Proline, Fl. Chl. = Flag leaf Chlorophyll, $\mathrm{RWC}=$ Relative water content, $\mathrm{CML}=\mathrm{Cell}$ membrane leakage 
Among the physiological traits considered, flag leaf chlorophyll content under drought stress is a better indicative of plant's ability to withstand drought stress by keeping it's photosynthetic machinery active (Farquhar et al., 1989) because water stress condition caused reduction in chlorophyll content (Iturbe et al., 1998). Among the genotypes, Sokoll and Sakha8 demonstrated highest amount of flag leaf chlorophyll followed by Shorawaki. However, drought stress caused least damage of leaf chlorophyll in Vorobey but highest in Sourav (Fig 1C). Flag leaf chlorophyll of all the locally cultivated genotypes might go through damage due to drought stress. Therefore, Sokoll and Sakha8 should be considered for improving the trait of concern.
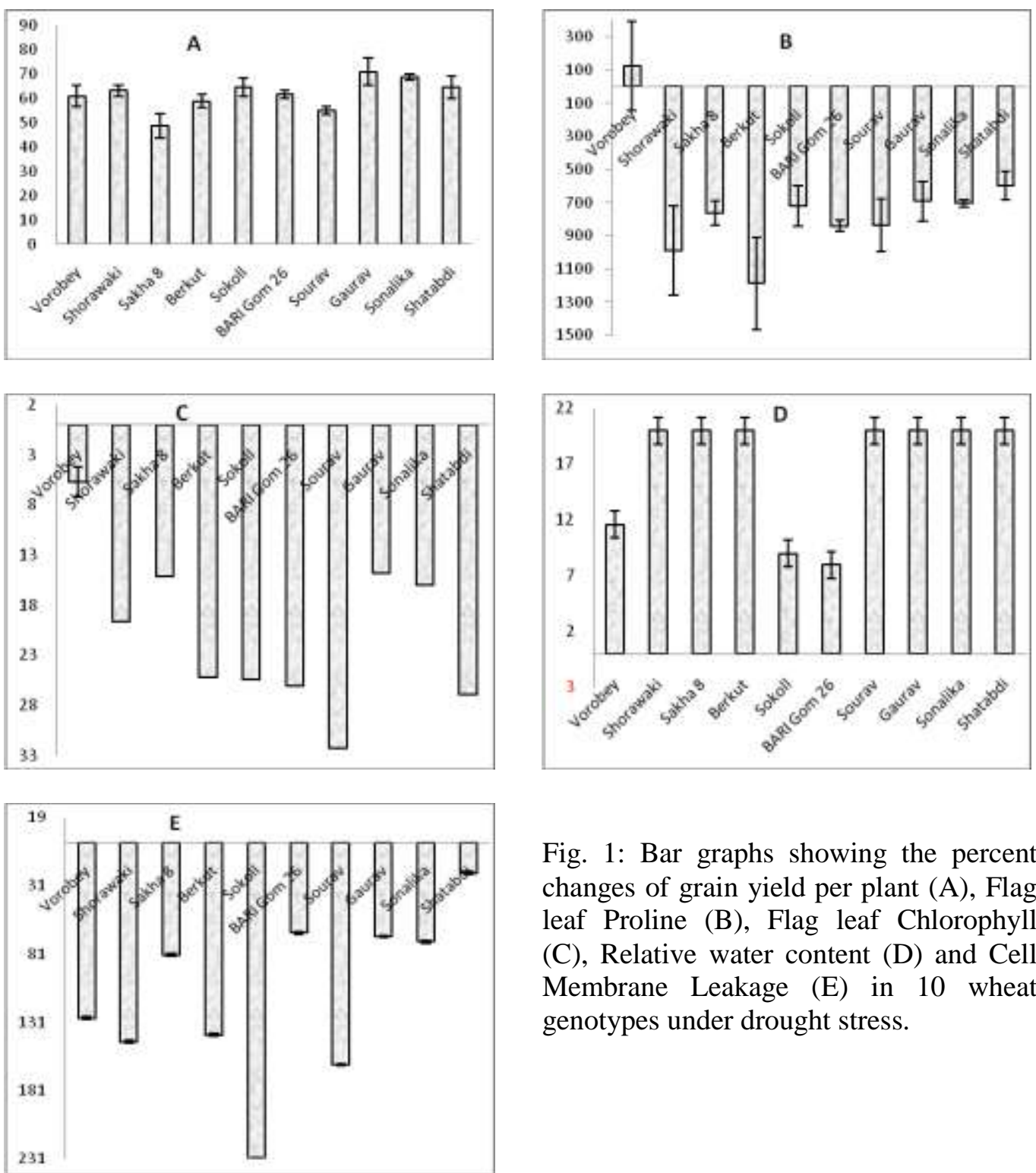

Fig. 1: Bar graphs showing the percent changes of grain yield per plant (A), Flag leaf Proline (B), Flag leaf Chlorophyll (C), Relative water content (D) and Cell Membrane Leakage (E) in 10 wheat genotypes under drought stress.

Another physiological trait, relative water content (RWC) was found highest in Sokoll and BARI Gom 26, followed by Vorobey and Sonalika. Leaf RWC is proposed as a more important indicator of water status than other water potential parameters under drought stress conditions. During plant development drought stress significantly reduced 
RWC values (Siddique et al., 2000). Among the genotypes, lowest reduction of RWC was found in BARI Gom 26, followed by Sokoll and Vorobey (Fig 1D). The deviation in RWC may be attributed to differences in the ability of the genotypes to absorb more water from the soil and, or the ability to control water loss through the stomata's. It may also be due to differences in the ability of the tested genotypes to accumulate and adjust osmotically to maintain tissue turgor and hence physiological activities (Almeselmani, 2010).

Moreover, cell membrane leakage was found lowest in Sakha8, Gourab. The leakage was due to damage to cell membranes which become more permeable (Senaratna and Kersie, 1983). Cell membrane is one of the first targets of plant stresses (Levitt, 1972) and the ability of plants to maintain membrane integrity under drought is what determines tolerance towards drought (Vieira da Silva et al., 1974). Water stress caused water loss from plant tissues which seriously impair both membrane structure and function (Cave, 1981; Buchanan et al., 2000).

\section{CONCLUSION}

Genotypes used in the study were identified with different types of drought tolerance mechanisms, viz., Berkut for earliness, Shatabdi for grain weight, BARI Gom 26 for spike and grain number, along with Vorobey, Berkut for enhanced biosynthesis of proline, Sokoll for undamaged leaf Chlorophyll content and relative water content, Sakha8, Gaurav, Sonalika and Shatabdi for membrane thermostability; Sakha8 and Sourav for improved stress tolerance index, can be used as breeding materials in future, to develop drought tolerant wheat variety.

\section{Acknowledgements}

Author is grateful to the Bangladesh University Grants Commission (UGC) for the funding the project (Project No. 2013/60/UGC) in 2013-2014.

\section{REFERENCES}

Adhikary SK, Alam MZ and Paul NK. 2009. Variation of Grain Growth of Wheat Cultivars Bangladesh J. Agril. Res. 34(3): 351-359.

Almeselmani M. 2010. Effect of High temperature on physiological characters and yield attributes of wheat genotypes. In: International Conference on Agricultural Productivity Increase: Challenges and Means of Developments, 28-30 November, Al-Furat University Campus and Directorate of Agriculture and Agrarian Reform, Der-Azzor, p 50.

Almeselmani M. 2011. Effect of Drought on Different Physiological Characters and Yield Component in Different Varieties of Syrian Durum Wheat. Journal of Agricultural Science Vol. 3, No. 3.

Bates LS, Waldren RP \& Teare ID. 1973. Rapid determination of free proline for water stress studies. Plant Soil 39: 205-208.

Bohnert H J, Nelson DE and Jensen RG. 1995. Adaptation to environmental stresses. Plant Cell. 7: 1099-1111.

Buchanan BB, Gruissem, W. \& Jones, R.L. (2000). Biochemistry and Molecular Biology of Plants.Amer. Soc. Plant Physiol. Rockville.

Cave G 1981. Water and membranes: The interdependence of their physico-chemical properties in the case of phospholipids head groups. Studiabiophysica, 91, 41-46.

Farshadfar E., Haghparast R. and Qaitoli M, 2008. Chromosomal localization of the genes controlling agronomic and physiological indicators of drought tolerance in barley using disomic addition lines. Asian Journal of Plant Science.7: 536-543.

Fernandez GCJ. 1992. Effective selection criteria for assessing stress tolerance. In: Kuo C. G., (ed.) Proc. Int. Sym. Adaptation of Vegetables and Other Food Crops in Temperature and Water Stress, Publication, Tainan, Taiwan. 
Hakim MA, Hossain A, Teixeira da Silva JA, Zvolinsky VP, Khan MM. 2012. Yield, protein and starch content of 20 wheat (Triticum aestivum L.) genotypes exposed to high temperature under late sowing conditions. J Sci Res 4 (2):477-489.

Hossain A, Teixeira da Silva JA. 2012. Phenology, Growth and Yield of Three Wheat (Triticum aestivum L.) Varieties as Affected by High Temperature Stress. Not Sci Biol, 4(3):97-109

Dodd IC, Whalley WR, Ober ES and Parry MAJ. 2011. Genetic and management approaches to boost UK wheat yields by ameliorating water deficits. J. Exp. Bot. Page 1 of 8 , doi:10.1093/jxb/err242

Iturbe O, Escuredo IPR, Arrese-Igor C, and Becana M. 1998. Oxidative damage in pea plants exposed to water deficit or paraquat. Plant Physiol. 116: 173-181.

Khakwani, A.A, Dennett, M. D. and Munir, M. 2011. Drought tolerance screening of wheat varieties by inducing water stress conditions. Songklanakarin J. Sci. Technol. 33 (2), 135-142

Levitt J. 1972. Responses of plants to environmental stresses.' (Academic Press: New York).

Maggio A, Miyazaki S, Veronese P, Fujita T, Ibeas JI, Damsz B, Narasimhan ML, Hasegawa PM, Joly RJ, Bressan RA. 2002. Does proline accumulation play an active role in stress-induced growth reduction. Plant J 31: 699-712.

Martin U, Alladru SG \& Bahari ZA. 1987.. Dehydration tolerance of leaf tissues of six woody angiosperm species.PhysiologiaPlantarum, 69, 182-186. doi:10.1111/j.13993054.1987.tb01964.x, http://dx.doi.org/ 10.1111/j.1399-3054.1987.tb01964.x

Pask AJD, Pietragalla J, Mullan DM and Reynolds MP. (Eds.). 2012. Physiological Breeding II: A Field Guide to Wheat Phenotyping. Mexico, D.F.: CIMMYT.

Pospíšilová J, Batková P. 2004. Effects of pre-treatments with abscisic acid and /or benzyladenine on gas exchange of French bean, sugar beet, and maize leaves during water stress and after rehydration. Biologia Plantarum 48, 395-399.

Punia SS, Shah AM and Ranwhaa BR. 2011. Genetic analysis for high temperature tolerance in bread wheat. African Crop Science Journal 19(30) 149 - 163.

Quarrie SA, LazicJanc`c V, Kovac`evic D, Steed A and Pekic S. 1999. Bulk segregant analysis with molecular markers and its use for improving drought resistance in maize. Journal of Experimental Botany, Vol. 50, No. 337, pp. 1299-1306

Rahman MM, Hossain A, Hakim MA, Kabir MR, Shah MMR. 2009. Performance of wheat genotypes under optimum and late sowing condition. Int J Sustain Crop Prod 4(6):34-39.

Reddy AR, Chaitanya, KV and Vivekanandan, M. 2004. Drought-induced responses of photosynthesis and antioxidant metabolism in higher plants. J. Plant Physiol, 161 (2004), pp. 1189-1202

Reynolds MP, Pierre CS, Saad ASI, Vargas M, Condon AG. 2007. Evaluating potential genetic gains in wheat associated with stress-adaptive trait expression in elite genetic resources under drought and heat stress. Crop Sci 47: S-172-S-189

Routley DG. 1966. Proline accumulation in wilted ladino clover leaves. Crop Sci. 6: 358-361.

Saeedipour S. and Moradi F. 2011. Comparison of the drought stress responses of tolerant and sensitive wheat cultivars during grain filling: impact of invertase activity on carbon metabolism during kernel development. African Journal of Biotechnology Vol. 10(72), pp. $16219-16227$

Saeedipour, S. and Moradi, F. 2011. Relationship between abscisic acid (ABA) concentration and some physiological traits in two wheat cultivars differing in post-anthesis drought resistance. African Journal of Biotechnology Vol. 10(72), pp. 16219-16227.

Senaratana T \&Kersi BD. 1983. Characterization of solute efflux from dehydration injured soybean (Glycine maxl, Merr.) seeds. Plant Physiology, 72, 911-914. doi:10.1104/pp.72.4.911, http://dx.doi.org/10.1104 /pp.72.4.911.

Siddiqui MRB, Hamid A and Islam MS. 1999. Drought stress effects on photosynthetic rate and leaf gas exchange of wheat. Bot. Bull. Acad. Sin. 40: 141-145.

Siddiqui MRB, Hamid A and Islam MS. 2000. Drought stress effects on water relations of wheat. Bot. Bull. Acad. Sin. 41: 35-39

Vieira da Silva J, Naylor AW \& Kramer PJ. 1974.. Some ultrastructural and enzymatic effects of drought stress in cotton (Gossypiumhirsutum L.) leaves. Proceedings of the National Academy of Sciences, 71, 3243-324. 